\title{
COVID-19 and disruptions to food systems
}

\author{
Tim G. Benton ${ }^{1}$
}

Accepted: 21 April 2020 / Published online: 12 May 2020

(c) Springer Nature B.V. 2020

We live in a world dominated by the neo-liberal idea that consumption-driven growth of economies, accessing globalised trade, is the best way to drive global development. Global competition drives down prices, allowing countries with comparative advantage to create goods for consumption elsewhere. Efficiency, in the name of cheaper goods, means redundancy is removed. The food system is a crucial exemplar of this: in the UK food comes into the country at more-or-less the speed it is sold in supermarkets.

The downside from supplying an abundance of cheap goods is that the globalised system is also fragile. If it breaks, then goods we rely on disappear off shelves and prices rocket. In 2007/2008 and again in 2010/2011 climate shocks, coupled with low transparency of international stocks, led to the perception that food would be rare, countries instituted export bans, markets panicked, international food prices spiked, and food riots broke out around the world (Homer-Dixon et al. 2015; Puma et al. 2015). Amongst other things, the food price riots sparked the Arab Spring (Natalini et al. 2017), contributing to a long-lasting geo-political reconfiguration of the Middle East.

The last decade's food price spikes created a focus on the potential for climate-change driven disruptions on food systems (Challinor et al. 2018). Climate change is not only about new extremes of weather that may disrupt on our food systems, but is also likely to create new challenges through new pests and diseases of crops and livestock, that disrupt agriculture: as climate changes, pests and diseases move, and there are opportunities for them to escape from natural ecological mechanisms that keep them under control (Bebber et al. 2013). These same issues also affect the diseases that

This article is part of the Topical Collection: Agriculture, Food \& Covid-19.

\footnotetext{
Tim G. Benton

TBenton@chathamhouse.org

1 Royal Institute of International Affairs, Chatham House, 10 St James Square, London SW1Y 4LE, UK
}

infect wildlife, and, potentially humans: like most emerging diseases, COVID-19 comes from wildlife.

As we change ecology, through habitat loss, degradation and climate change we change the way animals, reservoirs, vectors and pathogens mix, paving the way for pathogens to leap into new hosts. Couple this with increasing urbanisation, wildlife encroaching on cities and people and animals interacting in new ways, emerging diseases may, likely climate change itself, be seen as a symptom of environmental degradation (Brooks et al. 2019).

In other words, extreme as it is, perhaps COVID is not a one-off, but more an exemplar of the short of disruptive shocks we need to adapt to in the Anthropocene.

As countries have locked-down to reduce COVID-19 spread, it has exposed the strengths and weaknesses of our food systems. Shoppers "stocking up", in response to rational needs, have led to empty shelves that just-in-time supply chains have struggled to cope with. Vulnerable people have been exposed by their inability to get to shops as home-delivery systems have been swamped by demand. Food prices are rising locally and globally. The amount of food available has not caused any problems to date: its distribution has.

Looking ahead, however, there is a potential problem in supply. In the Northern Hemisphere, planting is largely over, but harvesting is soon to come. What happens if the labour is not available? Harvests in the early-maturing fresh produce areas in southern Europe has been problematic due to "social distancing" and labour shortages.

In the southern hemisphere, harvesting is underway, just as lock-downs roll out. For large scale mechanised farms, harvesting will continue, but for smaller farming systems, manual labour is key. Will supply become an issue, as well as distribution? Some countries clearly think so, as they start to introduce export bans to keep food within their bordersexactly the policies that drove the last food price spikes.

Once harvests are done, farmers then have to decide what to plant. They therefore have to bet on what foods there will be demand for in the following months. With so much change in demand driven by changing markets, supply 
chains and lock-downs there is huge uncertainty about what demand might be in the months ahead: will farmers make the right decisions, and who will guide them, to ensure the effects of COVID do not ripple into global food disruptions?

So COVID-19 might contribute to food supply issues in the following months. On top of that, 2020 is already shaping up to be a very hot year from a climate perspective. At a time when our food systems are under significant pressures, there is capacity to absorb any other supply-side shock-whether from a drought, heatwave or locust swarm. Recovery from a deep recession will be so much harder if food prices go through the roof: the poor and vulnerable will, as ever, suffer most.

Will COVID-19, as an exemplar of a shock to our globalised systems, promote us to reconstruct it in a way that puts people and the planet's well-being at its heart? Or will we simply seek to recover our unhealthy, unsustainable but consumption-promoting economy?

\section{References}

Bebber, Daniel P., Mark A.T. Ramotowski, and Sarah J. Gurr. 2013. Crop pests and pathogens move polewards in a warming world. Nature Climate Change 3: 985-988. https://doi.org/10.1038/nclim ate 1990.

Brooks, D.R., Eric P. Hoberg, and Walter A. Boeger. 2019. The Stockholm paradigm : Climate change and emerging disease. Chicago: University of Chicago Press.

Challinor, Andy J., W. Neil Adger, Tim G. Benton, Declan Conway, Manoj Joshi, and Dave Frame. 2018. Transmission of climate risks across sectors and borders. Philosophical Transactions of the Royal Society A: Mathematical, Physical and Engineering Sciences 376: 20170301. https://doi.org/10.1098/rsta.2017.0301.

Homer-Dixon, Thomas, Brian Walker, Reinette Biggs, Anne-Sophie Crépin, Carl Folke, Eric F. Lambin, Garry D. Peterson, et al. 2015. Synchronous failure: The emerging causal architecture of global crisis. Ecology and Society. https://doi.org/10.5751/ES-07681 -200306 .

Natalini, Davide, Giangiacomo Bravo, and Aled Wynne Jones. 2017. Global food security and food riots-an agent-based modelling approach. Food Security. https://doi.org/10.1007/s1257 1-017-0693-z.

Puma, Michael J., Satyajit Bose, So Young Chon, and Benjamin I. Cook. 2015. Assessing the evolving fragility of the global food system. Environmental Research Letters 10: 24007.

Publisher's Note Springer Nature remains neutral with regard to jurisdictional claims in published maps and institutional affiliations.

Professor Tim Benton is Research Director in Emerging Risks at the Royal Institute of International Affairs at Chatham House and Professor at the University of Leeds, where he was formerly, Dean of Strategic Research Initiatives. From 2011-2016 he was the "Champion" of the UK's Global Food Security programme which is a multi-agency partnership of the UK's public bodies (government departments, devolved governments and research councils) with an interest in the challenges inherent in delivering food security around the world. He was an IPCC author on the Special Report on Food, Land and Climate, and an Agenda Steward of the World Economic Forum. He has published over 150 academic papers, many on the topics of agriculture and its sustainability. His particular interest is currently on food system resilience in the face of climate change. 